\title{
Notes on COVID 19 and the contradictions of capital II
}

\author{
Anthony Marcus ${ }^{1} \cdot$ Winnie Lem ${ }^{2}$
}

Published online: 3 March 2021

(c) The Author(s), under exclusive licence to Springer Nature B.V. part of Springer Nature 2021

\section{Call for commentaries}

This call for commentaries is a one year follow- up to Notes on COVID 19 and the Contradictions of Capital, a symposium published in the September 2020 issue of Dialectical Anthropology (44:3)

In our second symposium on COVID 19, we ask for commentaries that explore the possibility for socialist resolutions to the current chaos. Given the prevalence of forces that undermine the political consciousness and concerted action of the international working class, it is clear that none of the political institutions that lead or seek to lead that class have the ability right now to engage in the type of robust long, or short term, forecasting and planning that appears to be happening in capitalist ruling class circles. Our call asks for contributions that seek to unpack and parse this planning and forecasting. We ask authors to critically consider what segments of the capitalist ruling class think the future looks like? What do they think the future should look like? What scenarios are they preparing for action and reaction? What are they up to and how are we responding, in the many places around the planet?

By contrast, what could a socialist solution and plan for a pandemic free future look like. We are currently being bombarded with headlines about British mutant viruses, South African and Brazilian variants, vaccine nationalism, one in a million allergic reactions, and the ubiquitous phrase "Coronavirus is here to stay". These narratives have not helped with our ability as a class to conceive and construct socialist resolutions. In the current heat of the pandemic moment, pessimism, fear, lack of hope, virus-inspired culture wars and divided polities and authoritarian solutions seems to be offered to stem the ravages of COVID-19. Indeed, the international bourgeoisie thrives in an atmosphere of chaos, fear, hopelessness, and social atomization. Perhaps this is the reason for wild runups in share prices amidst death,

Anthony Marcus

toniomar@yahoo.com

Winnie Lem

wlem@trentu.ca

1 City University of New York, New York, NY, USA

2 Trent University, Peterborough, Canada 
conflict, combat, "virus fatigue", the wholesale destruction of small businesses, and the ruination of petty bourgeoisies across the planet, many of whom seem to increasingly view nationalism, fascism, and nostalgia as the only solution to their untenable present and hopeless future.

While it is challenging to look to the future when the present is so chaotic, we ask contributors for insights that focus on different global contexts and to consider, from a socialist perspective, such questions as:

What will the future look like?

What should the future look like?

How do we get from here to there?

What class forces are at work, who are their antagonists and what are they doing? 